九州大学学術情報リポジトリ

Kyushu University Institutional Repository

\title{
Tolerance Differences among Small Seed Soybean Cultivars against Excessive Water Stress Conditions
}

Cho, Jin-Woong

Collage of Agricultural and Life Science, Chungnam National University

Yamakawa, Takeo

Faculty of Agriculture, Kyushu University

https://doi.org/10.5109/9229

出版情報：九州大学大学院農学研究院紀要. 51 (2)，pp. 195-199，2006-10-27. Faculty of Agriculture, Kyushu University

バージョン：

権利関係 : 


\title{
Tolerance Differences among Small Seed Soybean Cultivars against Excessive Water Stress Conditions
}

\author{
Jin-Woong $\mathrm{CHO}^{1}$ and Takeo YAMAKAWA* \\ Laboratory of Plant Nutrition, Division of Soil Science and Plant Production, \\ Department of Plant Resources, Faculty of Agriculture, Kyushu University, \\ 6-10-1 Hakozaki, Fukuoka 812-8581, Japan. \\ (Received May 22, 2006 and accepted July 24, 2006)
}

\begin{abstract}
Objectives of this study are to determine tolerance variability of small seed soybean cultivars against the excessive water stress (EWS) at V4 to V5 stage, and to provide the basic data to the parental selection for breeding. This experiment carried out on a concrete bed filled up with silt loam soil in greenhouse using 22 small seed soybean cultivars.

The seed yield of 22 soybean cultivars treated with EWS for 10 days at V4 to V5 stage ranged from $42 \mathrm{~g}$ $\mathrm{m}^{-2}$ to $179 \mathrm{~g} \mathrm{~m}^{-2}$. Sowonkong was the greatest yield $179 \mathrm{~g} \mathrm{~m}^{-2}$, and Pureunkong and Sorogkong were the lowest yield $42 \mathrm{~g} \mathrm{~m}^{-2}$. The mean pod numbers of 22 soybean cultivars treated with non-EWS and EWS were 58.6 and 37.1 per plant, respectively. The number of seed of soybeans treated with EWS also decreased about $49 \%$ of that with non-EWS.

The correlation coefficient was slightly higher in 20 days $(r=0.459, \mathrm{p}<0.05)$ after the removal of excessive water stress (REWS) treatment than in 10 days $(r=0.428, p<0.05)$ after REWS. Also, the relationship between the relative seed yield and the relative number of pods per plant was positive correlation $(\mathrm{r}=0.542, \mathrm{p}<0.01)$ under EWS for 10 days. On the other hand, the relationship between the relative seed yield and the number of seeds per plant was high positive correlation $(r=0.945, p<0.001)$ under EWS for 10 days.

These results with 22 small seed soybean cultivars indicated significant differences among cultivars for biomass, yield, and yield components. Sowonkong could be thought to be highest possibilities as a cultivar of excessive productivity under EWS conditions. Also, the above data suggest that the variability for flooding tolerance exists among small seed soybean cultivars and could be improved through repeating selection under EWS for 10 days at vegetative stage.
\end{abstract}

\section{INTRODUCTION}

Since soybean includes the high content of protein and fat, it is widely used as foods, industries and forages, and the production and consumption increases every year in worldwide. But, in Korea, because the yield and income per unit area of soybean was very low and the application of mechanization technology is insufficient, the cultivated area of soybean decreased rapidly by 297,000 ha in 1970 to 87,350 ha in 2000. The self-supply of soybean is not more than $24.6 \%$ in 2000 . Therefore, in order to elevate self-supply of soybean, it is essential to enlarge the yield per unit area. Also, it is very important to extend a cultivated area, to apply new cultivation techniques and to develop high quality cultivars (Cho et al., 2003; Cho et al., 2004; Park et al., 2001).

The growth and yield of soybean were affected by the water condition during the growing season and the significant amount of water was required during the growth of soybean. The effect of excess water is known as aeration stress and the insufficient water was referred to as drought stress (Scott et al., 1989). The damage on plant by the excessive water stress (EWS) is usually attributed to an insufficient oxygen supply to maintain the root respiration. EWS inhibits nitrogen and mineral

${ }^{1}$ Division of Plant Science and Resources, Collage of Agricultural and Life Science, Chungnam National University, 305-764, Korea

* Corresponding author (E-mail: yamakawa@agr.kyushu-u.ac.jp) uptake, and inhibits root growth and nodulation in soybean (Sallan and Scott, 1987). The flood influences on the soybean were manifested in the yellowing and abscission of leaves at the lower nodes, and the stunting of occurrence. Also those reduced the dry matter accumulation and the seed yield of soybean (Scott et al., 1989).

The greater sensitivity to EWS was shown during the early reproductive (R1 to R5, Fehr et al., 1971) compared to the vegetative periods (Emergence to R1). EWS sensitivities at specific developmental stages throughout soybean's life cycle have not been identified, but the greatest sensitivity to EWS occurred at R3 stage (Linkemer et al., 1998). EWS for as little as 2 days reduced soybean yield by $18 \%$ at the V4 stage (Fehr and Cavines, 1977) and 26\% at the R2 stages (Scott et al., 1989). Yields were generally similar when flood periods were 1 to 2 days but when flood periods were held longer than 2 days at R2 stage, the average yield was about 50\% compared to non-treated plant (Griffin and Saxton, 1988). Also, the determinate soybean cultivars were more susceptible to prolonged EWS during early reproductive growth than early vegetative growth (Griffin and Saxton, 1988). Soybean genetic lines from southeastern China were adapted to high water table conditions (Ralph, 1983) and appeared more tolerant to simulated laboratory EWS conditions than some soybean cultivars from the Midwest (van Toai et al., 1993). The flood tolerance of 84 U.S. soybean cultivars had been fully tested under field conditions by van Toai et al. 
(1994). They reported that 84 soybean cultivars indicated significant differences among cultivars for the seed yield at a flooded field. Also, Choi et al. (1995, 1996) reported that the reduction of soybean yield at the vegetative growth stage was mainly due to the decrease of stem dry weight under excessive soil water stress.

Thus, objectives of this study are to determine the tolerant variability of small seed soybean cultivars against EWS at V4 to V5 growth stage and to provide the basic data to the parental selection for breeding.

\section{MATERIALS AND METHODS}

This experiment carried out on a concrete bed (11 m $\times 2 \mathrm{~m} \times 1 \mathrm{~m}$ ) filled up with silt loam soil in greenhouse using 22 small seed soybean cultivars listed up in Table 1. Seeds were sowed with a planting density of $50 \mathrm{~cm} \times$ $10 \mathrm{~cm}$. The amount of applied fertilizer was $\mathrm{N} ; 3 \mathrm{~g}, \mathrm{P}$; $3 \mathrm{~g}$, and $\mathrm{K} ; 4 \mathrm{~g}$ per $\mathrm{m}^{2}$ as basal fertilizations. Plants were grown under photoperiod of natural light with day temperature of $35.6 \pm 5.3^{\circ} \mathrm{C}$ and night temperature of $18.2 \pm$ $1.7^{\circ} \mathrm{C}$.

The excessive water stress (EWS) was done for 10 days when plants were at V4 to V5 stages by filling the bed with tap water to $1 \mathrm{~cm}$ above the level of soil surface. Experimental design was a completely randomized design with three replications.

The data of dry matter were taken at the last day of EWS treatment, and at 10 and 20 days after the removal of excessive water stress (REWS), respectively. For measurement of dry weight whole plant's parts were separated into stem and leaf and dried for 3 days in a forced-air dryer at $80^{\circ} \mathrm{C}$. The data of seed yield and yield components were obtained in a manner similar to that described for the field study (Cho et al., 2005).

\section{RESULTS AND DISCCUTION}

The seed yield of non-EWS in 22 soybean cultivars ranged from 171 to $286 \mathrm{~g} \mathrm{~m}^{-2}$ (Table 1 ). Cultivar differences were significant, which LSD $(p<0.01)$ was $27 \mathrm{~g}$ $\mathrm{m}^{-2}$. The seed yield of 22 soybean cultivars treated with EWS for 10 days at V4 to 5 stages ranged from 42 to $179 \mathrm{~g} \mathrm{~m}^{-2}$. According to Scott et al. (1989), seed yield of soybean after 14 days of flood periods at R2 stage ranged from 2344 to $2853 \mathrm{~kg} \mathrm{ha}^{-1}$ on Crowley silt loam soil and 951 to $1829 \mathrm{~kg} \mathrm{ha}^{-1}$ on Shatkey clay soil and the rate of yield reduction was $157 \mathrm{~kg} \mathrm{ha}^{-1}$ per day of the flood for the soybean flooded at R2 stage on the Sharkey clay. Also, on the Crowley silt loam, yield reduction rate was $101 \mathrm{~kg} \mathrm{ha}^{-1}$ per day of the flood duration for the soybean flooded at R2 stage. Van Toai et al. (1994) reported that the average seed yield of 84 soybean cultivars at excessive rainfall (17 cm more than normal) was $25 \%$ lower than that at the non-flooded area and the seed yield of these cultivars ranged from 1.27 to $3.70 \mathrm{Mg} \mathrm{ha}^{-1}$. Mochizuki and Matsumoto (1991) reported that the seed weight of 12 cultivars was reduced but that of eight cultivars was not reduced by the excessive moisture

Table 1. Seed yield and yield components in 22 soybean cultivars treated with EWS for 10 days at V4 to V5 stage

\begin{tabular}{|c|c|c|c|c|c|c|c|c|c|c|c|c|}
\hline \multirow{2}{*}{ Cultvars } & \multicolumn{3}{|c|}{$\begin{array}{c}\text { Pod } \\
\left(\text { No. plant }^{-1}\right)\end{array}$} & \multicolumn{3}{|c|}{$\begin{array}{c}\text { Seed } \\
\left(\text { No. plant }{ }^{-1}\right)\end{array}$} & \multicolumn{3}{|c|}{$\begin{array}{l}\text { Seed weight } \\
\left(\text { g } 100 \text { seed }^{-1}\right)\end{array}$} & \multicolumn{3}{|c|}{$\begin{array}{l}\text { Seed yield } \\
\quad\left(\mathrm{g} \mathrm{m}^{-2}\right)\end{array}$} \\
\hline & $\begin{array}{l}\text { Non- } \\
\text { EWS }\end{array}$ & EWS & $\begin{array}{c}\text { Relative } \\
\text { value (\%) }\end{array}$ & $\begin{array}{l}\text { Non- } \\
\text { EWS }\end{array}$ & EWS & $\begin{array}{c}\text { Relative } \\
\text { value (\%) }\end{array}$ & $\begin{array}{l}\text { Non- } \\
\text { EWS }\end{array}$ & EWS & $\begin{array}{c}\text { Relative } \\
\text { value (\%) }\end{array}$ & $\begin{array}{l}\text { Non- } \\
\text { EWS }\end{array}$ & EWS & $\begin{array}{c}\text { Relative } \\
\text { value (\%) }\end{array}$ \\
\hline Sohokong & 63.6 & 49.8 & 78 & 92.9 & 45.4 & 49 & 9.8 & 8.6 & 88 & 255 & 109 & 43 \\
\hline Tawonkong & 56.2 & 42.7 & 76 & 86.5 & 54.6 & 63 & 9.8 & 6.9 & 70 & 238 & 106 & 44 \\
\hline Pureunkong & 48.9 & 25.0 & 51 & 79.3 & 18.7 & 24 & 10.4 & 8.2 & 79 & 232 & 42 & 19 \\
\hline Eunhakong & 46.4 & 25.2 & 54 & 58.8 & 28.1 & 48 & 10.9 & 9.0 & 83 & 179 & 70 & 39 \\
\hline Namhaekong & 66.6 & 36.2 & 54 & 78.2 & 42.8 & 55 & 12.4 & 10.2 & 82 & 274 & 123 & 45 \\
\hline Bukwangkong & 57.6 & 37.8 & 66 & 75.5 & 53.0 & 70 & 12.5 & 11.4 & 91 & 263 & 168 & 64 \\
\hline Hannamkong & 65.8 & 34.1 & 52 & 82.3 & 34.1 & 41 & 9.4 & 8.2 & 87 & 216 & 78 & 36 \\
\hline Iksannamulkong & 47.3 & 36.7 & 77 & 71.3 & 52.7 & 74 & 11.9 & 10 & 84 & 238 & 148 & 62 \\
\hline Sobaegnamulkong & 63.0 & 35.9 & 57 & 84.4 & 29.7 & 35 & 9.3 & 9.2 & 99 & 218 & 76 & 35 \\
\hline Myeongjunamulkong & 65.8 & 40.1 & 61 & 96.8 & 50.2 & 52 & 9.6 & 8.1 & 84 & 260 & 115 & 44 \\
\hline Doremikong & 50.1 & 35.1 & 70 & 88.7 & 56.8 & 64 & 10.1 & 9.4 & 93 & 252 & 148 & 60 \\
\hline Saebyeolkong & 51.9 & 22.3 & 43 & 77.2 & 31.5 & 41 & 12.3 & 10.5 & 85 & 266 & 92 & 35 \\
\hline Pungsannamulkong & 56.7 & 47.2 & 83 & 95.7 & 58.3 & 61 & 9.7 & 8.7 & 90 & 260 & 143 & 55 \\
\hline Somyeongkong & 65.2 & 45.4 & 70 & 94.2 & 50.8 & 54 & 8.9 & 7.1 & 80 & 235 & 101 & 43 \\
\hline Paldokong & 58.2 & 36.9 & 63 & 67.5 & 29.6 & 44 & 10.1 & 7.8 & 77 & 190 & 64 & 34 \\
\hline Sowonkong & 71.9 & 55.8 & 78 & 110.2 & 71.9 & 65 & 9.3 & 8.9 & 96 & 286 & 179 & 62 \\
\hline Kwangankong & 56.1 & 31.9 & 57 & 72.3 & 34.5 & 48 & 11.1 & 9.5 & 86 & 224 & 92 & 41 \\
\hline Sunamkong & 78.5 & 39.3 & 50 & 94.0 & 51.8 & 55 & 8.7 & 8.6 & 99 & 230 & 126 & 54 \\
\hline Dagikong & 53.1 & 27.3 & 51 & 70.6 & 40.8 & 58 & 12.2 & 9.7 & 80 & 241 & 112 & 46 \\
\hline Dachaekong & 57.2 & 42.6 & 74 & 92.4 & 45.9 & 50 & 8.5 & 6.5 & 76 & 221 & 84 & 38 \\
\hline Anpyeongkong & 49.4 & 33.7 & 68 & 67.6 & 32.5 & 48 & 9.0 & 7.4 & 82 & 171 & 67 & 40 \\
\hline Sorogkong & 59.6 & 30.5 & 51 & 81.4 & 18.5 & 23 & 8.9 & 8.0 & 90 & 202 & 42 & 20 \\
\hline Mean & 58.6 & 37.1 & 63 & 82.6 & 42.4 & 51 & 10.2 & 8.7 & 85 & 234 & 104 & 44 \\
\hline
\end{tabular}

Non-EWS: Plant treated with non-EWS, EWS: Plant treated with EWS, Relative value (\%): (Value of plant with EWS)/(Value of plant with non-EWS) $\times 100$ 
conditions at paddy field. In this study, Sowonkong showed the greatest seed yield of $286 \mathrm{~g} \mathrm{~m}^{-2}$, and Anpyeongkong showed the lowest value of $171 \mathrm{~g} \mathrm{~m}^{-2}$ at non-EWS. The seed yield under EWS for 10 days at V4 to V5 stages, Sowonkong was the greatest one of $179 \mathrm{~g}$ $\mathrm{m}^{-2}$, and Pureunkong and Sorogkong were the lowest one of $42 \mathrm{~g} \mathrm{~m}^{-2}$. Also, the relative seed yield of the soybean under EWS to that under non-EWS (control plant), showed the greatest value of $64 \%$ in Bukwangkong and showed the greater value in order of Iksannamulkong, Sowonkong, Doremikong and Pungsannamulkong (Fig. 1).

The number of pods per plant treated with non-EWS and EWS in 22 soybean cultivars (Table 1) ranged from 46.4 to 78.5 and ranged from 22.3 to 55.8 , respectively. The average pod numbers of 22 soybean cultivars grown under non-EWS and EWS were 58.6 and 37.1 per plant, respectively. That of soybean treated with EWS was about 37\% lower than that with non-EWS. Pungsannamulkong showed the highest relative pod number of $83 \%$, but Saebyeolkong showed the lowest relative one of $43 \%$ under EWS for 10 days. According to Sugimoto et al. (1988), the reduction of seed yield of soybean on excessive moisture injury at flowering stage was due to decrease in the number of pods. Griffin and Saxton (1988), however, reported that the number of pods per soybean plant did not change with flood treatment regardless of flood period. The number of pods was the yield component most affected by waterlogging. Yield reduction by EWS at the vegetative stage was entirely related to fewer reproductive nodes. The reduction of reproductive nodes was related to lower stem dry matter. The effect of EWS at the

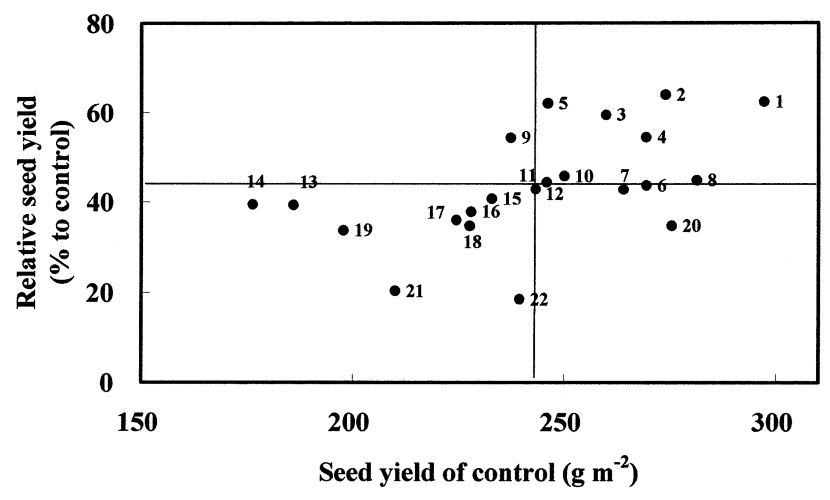

Fig. 1. Relationship between the relative seed yield of soybean cultivar treated with EWS for 10 days at V4 to V5 stages against control and the seed yield of control of 22 small seed soybean cultivars. Across line show the average of relative seed yield of soybean treated with EWS against the seed yield of control and the vertical line was the average of seed yield of small seed soybeans treated with non-EWS. 1. Sowonkong, 2. Bukwangkong, 3. Doremikong, 4. Pungsannamulkong, 5. Iksannamulkong, 6. Myeongjunamulkong, 7. Sohokong, 8. Namhaekong, 9. Sunamkong, 10. Dagikong, 11. Somyeongkong, 12. Tawonkong, 13. Eunhakong, 14. Anpyeongkong, 15. Kwangankong, 16. Dachaekong, 17. Hannamkong, 18. Sobaegnamulkong, 19. Paldokong, 20. Saebyeolkong, 21. Sorogkong, 22. Pureunkong. vegetative stage can be explained because stress at this time influenced canopy assimilation capacity and fertility after anthesis. Therefore, reduction of canopy assimilation capacity and fertilizing ability in soybean by EWS may be decreased to pods number (Linkemer et al., 1998)

The number of seed of soybeans treated with EWS also decreased about 49\% compared to that with non-EWS (Table 1). The reduced levels of seed numbers treated with EWS compared to that with non-EWS ranged from $23 \%$ to $74 \%$ in 22 small seed soybean cultiuvars. Also, the seed weight was decreased by EWS for 10 days at V4 to 5 stage but the reduction of seed weight was lower than any other yield components because the growth conditions at seed filling periods were really the same between EWS and non-EWS. However, the seed weight was affected when EWS was applied at reproductive stage and the seed weight reduction must have occurred through reduced growth rate (Linkemer et al., 1998).

Soybean is sensitive crop against EWS and generally, it influences especially the growth and yield during V4 to R5 stage. Soybean flooded at vegetative stage reduced leaf area, leaf dry weight and plant dry weight (Choi et al., 1996; Choi et al., 1995; Griffin and Saxton, 1988; Linkemer et al., 1998; Scott et al., 1989). Specially, Griffin and Saxton (1988) stated that soybean flooded at V6 had severe chlorosis and stunting on 4 days after flooding. Also, these researchers reported that crop growth rate (CGR) had been usually decrease when the EWS was applied for more than 2 days.

The dry weight of leaf and stem of the 22 soybean cultivars in the control (non-EWS) ranged from 0.54 to $1.63 \mathrm{~g}$ and from 0.36 to $0.93 \mathrm{~g}$ per plant, respectively (data not shown). Also, the average dry weight of leaf and stem of these cultivars was 0.91 and $0.70 \mathrm{~g}$ per plant, respectively (data not shown). The dry weight of leaf and stem of 22 soybean cultivars treated with EWS ranged from 0.49 to $1.50 \mathrm{~g}$ and from 0.31 to $0.92 \mathrm{~g}$ per plant, respectively (data not shown). The average dry weight leaf and stem of soybean treated with EWS was 0.69 and $0.48 \mathrm{~g}$ per plant, respectively (data not shown). The relative dry weight of leaf and stem treated with EWS to that with non-EWS in 22 soybean cultivars was $75.8 \%$ and $68.6 \%$, respectively (Table 2). Scott et al. (1989) reported that dry weights of the 14-days flooded soybean tended to be lower than those for the 2-days flooded soybean. This indicated that prolonged flooding was detrimental factor to dry matter accumulation. Also, there was a high significance between yield and canopy height or dry matter to flooding at V4, and canopy height and dry matter decreased linearly with duration of the flood at same time (Scott et al., 1989). Bacanamwo and Purcell (1999) reported that the reduction of shoot dry matter of soybean treated with EWS for 7 days and 14 days at V4 to V6 stage was due to decrease in leaf area and the root/shoot ratio tended to increase at flooding stress. In this study, the number of leaf also decreased by EWS for 10 days during vegetative stage, and it was thought that the reduction of leaf num- 
Table 2. The mean and coefficient of variation (CV) and relative value of dry matter, plant height, yield components and seed yield of 22 small seed soybean cultivars treated with EWS for 10 days at V4 to V5 stages against each value treated with non-EWS

\begin{tabular}{|c|c|c|c|c|c|c|}
\hline \multirow{2}{*}{ Traits } & \multicolumn{2}{|c|}{ Control (non-EWS) } & \multicolumn{2}{|c|}{ Treatment (EWS) } & \multicolumn{2}{|c|}{ Relative value to control } \\
\hline & Mean & $\mathrm{CV}(\%)$ & Mean & $\mathrm{CV}(\%)$ & Mean & CV (\%) \\
\hline Leaf DM (g plant ${ }^{-1}$ ) & 0.91 & 26.1 & 0.69 & 23.4 & 75.8 & 26.1 \\
\hline Stem DM (g plant ${ }^{-1}$ ) & 0.70 & 22.8 & 0.48 & 26.4 & 68.6 & 24.9 \\
\hline TDM (g plant $\left.{ }^{-1}\right)$ & 1.61 & 19.7 & 1.17 & 23.1 & 72.7 & 22.3 \\
\hline Plant height $(\mathrm{cm})$ & 69.7 & 13.6 & 48.3 & 21.4 & 69.3 & 23.3 \\
\hline Node no. of main stem (plant ${ }^{-1}$ ) & 9.0 & 10.1 & 7.3 & 12.6 & 81.1 & 12.1 \\
\hline Leaf no. $\left(\right.$ plant $\left.^{-1}\right)$ & 36.5 & 21.3 & 24.0 & 14.3 & 65.8 & 16.0 \\
\hline Pod no. (plant ${ }^{-1}$ ) & 58.6 & 13.8 & 37.1 & 20.5 & 63.3 & 17.7 \\
\hline Seed no. $\left(\right.$ plant $^{-1}$ ) & 82.6 & 14.3 & 42.4 & 30.9 & 51.3 & 23.2 \\
\hline 100 seed weight (g) & 10.2 & 11.6 & 8.7 & 11.9 & 85.3 & 8.0 \\
\hline Seed weight (g plant ${ }^{-1}$ ) & 8.4 & 11.9 & 3.7 & 33.5 & 44.0 & 25.4 \\
\hline
\end{tabular}

DM: dry matter, TDM: total dry matter.

ber was related to decrease the biomass accumulation and $\mathrm{CO}_{2}$ assimilation.

On the other hand, in each relative yield component in 22 soybean cultivar of EWS for 10 days against non-EWS (Table 2), the relative 100 seed weight showed the highest value $85.3 \%$, and the relative seed number showed the lowest value 51.3\%. The relative total dry matter of soybean treated with EWS against that with non-EWS was $72.7 \%$ and it was higher reduction in stem dry matter than that of leaf dry matter. Figure 2 shows relationships between the relative seed yield and the relative dry matter at last day with EWS, 10 days after REWS and 20 days after REWS. The relative dry matter of 22 soybean cultivars at last days with EWS was 73\%. It was tended to be that those values of 10 and 20 days after REWS were lower than that with EWS for 10 days. That is, it was ranged from 51\% to $91 \%$ on 10 days treated with EWS, ranged from $36 \%$ to $75 \%$ on 10 days after REWS and ranged from $40 \%$ to $72 \%$ on 20 days after REWS. Also, the relative seed yield of soybeans was $44 \%$ on the average and it was ranged from $19 \%$ to $64 \%$. This relative value showed no correlation $(r=0.385 \mathrm{~ns})$ with the relative dry matter of soybean cultivars at EWS for 10 days but there were a correlation between the relative seed yield and the relative dry matter of 22 soybean cultivars on 10 and 20 days after REWS. The correlation coefficient was slightly higher in 20 days $(r=0.459, \mathrm{p}<0.05)$ than in 10 days $(r=0.428, p<0.05)$ after REWS of 22 soybean cultivars. Therefore, it may be indicated that the distinction time of tolerant level against EWS among soybean cultivars was performed on 10 days after REWS.

Furthermore, the relationship between the relative seed yield and the relative number of pods per plant was positive correlation $(r=0.542, \mathrm{p}<0.01)$ with EWS for 10 days. Also, high positive correlation $(\mathrm{r}=0.945, \mathrm{p}<$ 0.001 ) between the relative seed yield and the relative number of seed per plant was found (Fig. 3). There was, however, no correlation between the relative seed yield and the relative seed weight on 22 soybean cultivars with EWS for 10 days.

These results with 22 small seed soybean cultivars indicated significant differences among cultivars for biomass, yield, and yield components. Sowonkong could
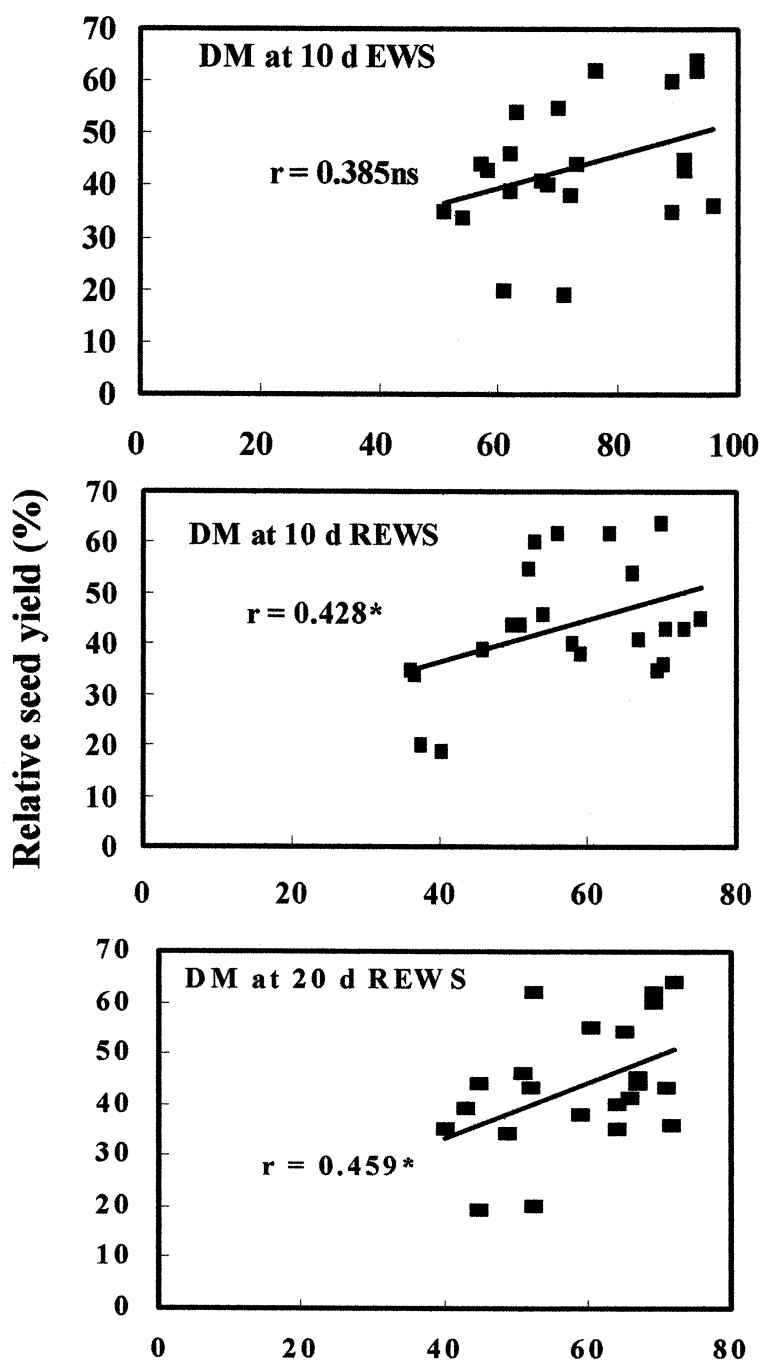

Relative dry matter (\%)

Fig. 2. Relationships between the relative seed yield of soybean cultivars treated with EWS for 10 days and the relative dry mater of soybean cultivars at last day treated with EWS for 10 days, at 10 days after REWS and at 20 days after REWS. $\mathrm{ns}$; not significant, *, and **; significant at $\mathrm{p}<0.05$, and $\mathrm{p}<0.01$, respectively. EWS; excessive water stress, REWS; removal of excessive water stress. 
be thought to be highest possibilities as a cultivar of excessive productivity under EWS conditions. Also, the above data suggest that the variability for flooding tolerance exists among small seed soybean cultivars and could be improved through repeating selection under EWS for 10 days at vegetative stage.

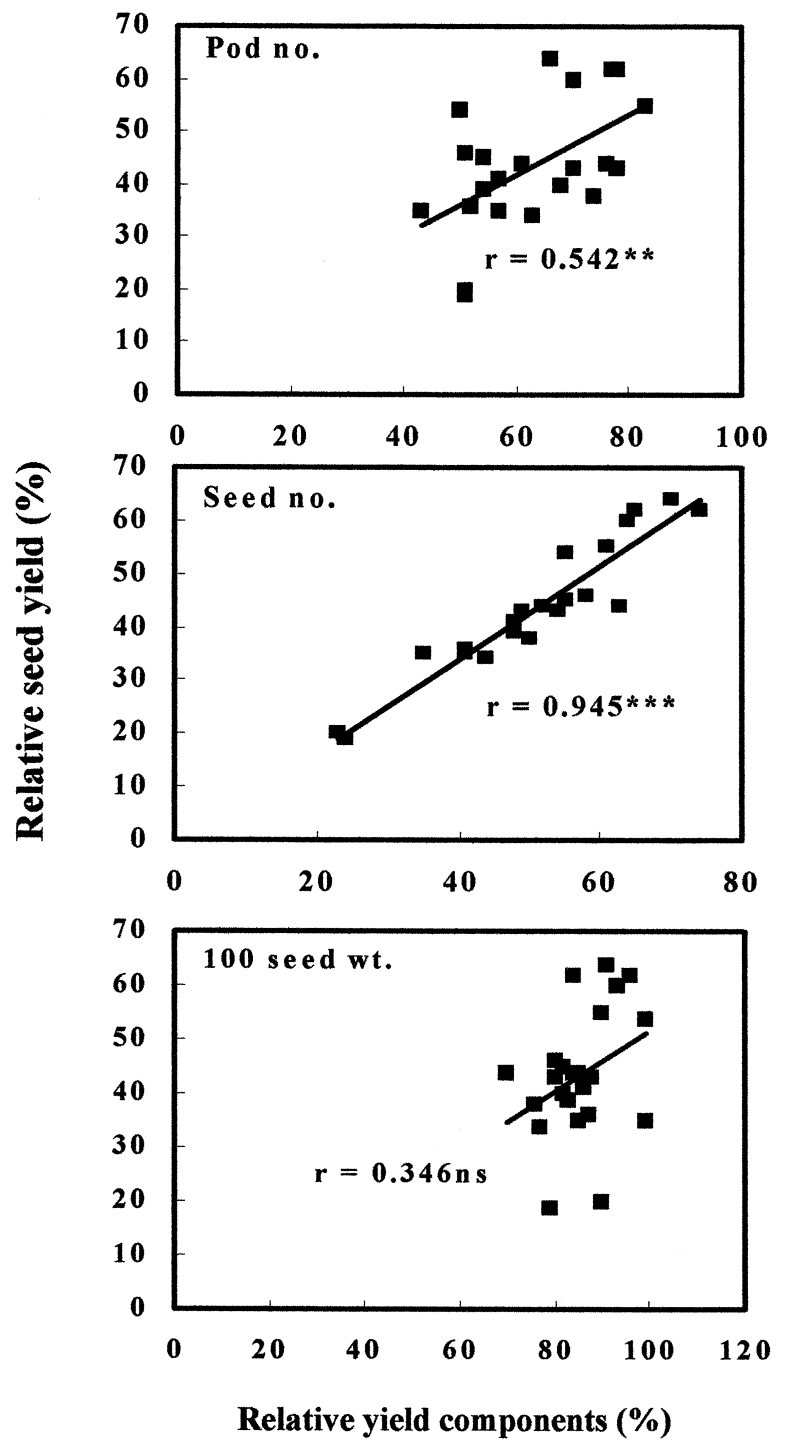

Fig. 3. Relationships between the relative seed yield and the relative yield components of soybean cultivars treated with EWS for 10 days against non-EWS plant. ns; not significant, **, and ***; significant at $\mathrm{p}<0.01$ and $\mathrm{p}<$ 0.001 , respectively.

\section{REFERENCES}

Bacanamwo, K. and L. Purcell 1999 Soybean root morphlogical and anatomical traits associated with acclimation to flooding. Crop Sci., 39: 143-149

Cho, J.-W., M. S. Park, J. J. Lee, M. J. Lee, J. D. So, T. S. Kim and S. B. Lee 2003 Topping effect on growth and yield of soybean growth in paddy field. Korean. J. Crop Sci., 48: 96-102

Cho, J.-W., J. J. Lee, Y. J. Oh, J. D. Lee and S. B. Lee 2004 Effects of planting densities and maturing types on growth and yield of soybean in paddy field. Korean J. Crop Sci., 49: 105-109

Cho, J.-W., G.-S. Park, T. Yamakawa and S. Ohga 2005 Comparison of yield in Korean small seed soybean cultivars with main stem and branch production. J. Fac. Agr. Kyushu Univ., 50: 511-519

Choi, K. J., H. S. Lee, S. D. Kim and E. H. Hong 1996 Dry matter and grain yield production of soybean cultivars as affected by excessive water stress at vegetative growth stage and flowering stage. RDA. J. Agri. Sci., 38: 117-122

Choi, K. J., H. S. Lee and Y. W. Kwon 1995 Physiological response of soybean under excessive soil water stress during vegetative growth period. Korean J. Crop Sci., 40: 595-599

Fehr, W. R., C. E. Caviness, D. T. Burmood and J. S. Pennington 1971 Stage of development descriptions for soybean, Glycine $\max$ (L.) Merrill. Crop Sci., 11: 929-931

Fehr, W. R. and C. E. Caviness. 1977 Stages of soybean development. Iowa Agric. Exp. Stn. Spec. Rep., $\mathbf{8 0}$.

Griffin, J. L. and A. M. Saxton 1988 Response of solid-seeded soybean to flood irrigation. II. Flood duration. Agron. J., 80: 885-888

Linkemer, G., J. E. Board and M. E. Musgrave 1998 Waterlogging effects on growth and yield components in late-planted soybean. Crop Sci., 38: 1579-1584

Mochizuki, T. and S. Matsumoto 1991 Varietal differences of wet endurance in autumn soybean plants. Jpn. J. Crop Sci., 60: 380-384

Park, H. K., Y. J. Oh, H. S. Kim, K. H. Kim, S. K. Suh and D. Y. Suh 2001 Future prospects for increase production of soybean. International symposium for 'Development strategy for self-production of soybean (Glycine $\max$ L.)'. NHAES. RDA. pp 79-121

Ralph, W. 1983 Soybeans respond to controlled waterlogging. Rural Res., 120: 4-8

Sallam, A. and H. D. Scott 1987 Effects of prolonged flooding on soybeans during early vegetative growth. Soil Sci., 144: $61-66$

Scott, H. D., J. DeAngulo, M. B. Daniels and L. S. Wood 1989 Flood duration effects on soybean growth and yield. Agron. J., 81: 631-636

Sugimoto, H., A. Amemiya, T. Satou and A. Takenoughi 1988 Excess moisture injury of soybeans cultivated in a upland converted from paddy. Jpn. J. Crop Sci., 57: 71-76

van Toai, T. T., J. Zhang and S. K. St. Martin 1993 RAPD markers of flooding tolerant Chinese soybean gerplasm. Soybean Genetics Newsl., 20: 153-159

van Toai, T. T., J. E. Beuerlein, A. F. Schmitthenner and S. K. St. Martin 1994 Genetic variability for flooding tolerance in soybean. Crop Sci., 34: 1112-1115 